\title{
PUBLIC DEBT INDEXATION AND DENOMINATION: THE CASE OF BRAZIL
}

\author{
Ilan Goldfajn \\ DOCUMENTOS DE TRABAJO DEL BANCO CENTRAL \\ $\mathrm{N}^{\circ} 27$ \\ Abril 1998 \\ Versión Revisada de Artículo presentado en la \\ Conferencia Internacional del Banco Central de Chile \\ "Indización, Inflación y Política Monetaria" \\ 11-12 de agosto, 1997
}




\title{
PUBLIC DEBT INDEXATION AND DENOMINATION: THE CASE OF BRAZIL
}

\author{
Ilan Goldfajn \\ International Monetary Fund
}

\section{Resumen}

El artículo modela la estrategia óptima de manejo de deuda del sector público cuando se emite deuda nominal, indexada al nivel de precios y denominada en moneda extranjera. El modelo predice que la varianza de la inflación, el tamaño de la deuda pública, la varianza del tipo de cambio real, y la correlación de la inflación con el gasto público son los principales determinantes del manejo de deuda pública. Usando este marco, el artículo analiza la experiencia brasileña con deuda indexada durante la década pasada. En particular, explica el gran aumento de la deuda pública en Brasil previa al plan Real de 1994, y su posterior y sostenida declinación.

\begin{abstract}
The paper models the optimal debt management strategy of the public sector when issuing nominal, pricelevel indexed and foreign denominated debt securities. The model predicts that the variance of inflation, the size of the public debt, the variance of the real exchange rate, and the correlation of inflation with public expenditures are the main determinants of public debt management. Using this framework, the paper analyzes the Brazilian experience with indexed debt in the last decade. In particular, it explains the large increase of indexed public debt in Brazil prior to the Real plan of 1994 and, thereafter, its steady decrease.
\end{abstract}

This paper was prepared for the Central Bank of Chile's conference on "Indexation, Inflation and Monetary Policy" on August 11-12, 1997. I would like to thank Trevor Alleyne, Márcio Garcia, Fernando Lefort, Klaus Schmidt-Hebbel and, Andrés Velasco for very useful comments. Also, to Ugo Fasano, Patrícia Menandro (Andima), Mário Mesquita, Áureo de Paula, and Evan Tanner for kindly providing me with the data. All errors are my own. 


\section{Introduction}

Since the Real plan of 1994, the Brazilian economy has been in the process of reducing its degree of indexation. For more than three decades, Brazilian wages, rents, financial securities and other contracts were indexed to the price level. At times the frequency of adjustment reached monthly intervals and even daily, as in the case of some financial securities.

An inseparable feature of Brazilian indexation was the association with high rates of inflation. The latter averaged 20 percent per month during the last 3 decades and reached its peak of 82 percent per month during the hyperinflation (or "megainflation") process just before the Collor Plan (see Figure 1). The association between inflation and indexation has always provoked the debate about whether high and variable inflation induces the indexation of the economy through the breakdown of nominal contracts or, in the opposite direction, indexation perpetuates the inflationary process as argued by the inertial theory of inflation. ${ }^{1}$

Brazilian indexation has relied mainly on price level indexation as opposed to exchange rate indexation, as is common in several other inflationary experiences. This peculiar feature has often been justified by the institutionality of Brazilian indexation mechanisms that dated back to 1964 and concentrated on price level indexation, well before the high inflation process of the late 1980's and early 1990's.

This paper investigates Brazilian indexation in the financial sector in the last few decades. In particular, the paper focuses on indexation of the public debt. Government indexed securities were not only a sizable portion of total securities but also took a central role (as reference values and even unit of account) in spreading indexation mechanisms to other contracts in the economy like wages, rents, taxes and other private financial contracts. There are several examples of important government indexed securities like the Obrigacoes Reajustaveis do Tesouro Nacional (ORTN and later OTN) from 1964-1989 or the Bonus do Tesouro Nacional (BTN) from 1989-1991.

The paper will examine the composition of public debt between pricelevel indexed, nominal and foreign denominated securities. It argues that the volatility of inflation, the level of total debt, the volatility of the real

\footnotetext{
${ }^{1}$ For this debate and the inertial inflation theory, see Arida and Resende (1985) and Simonsen(1983). Also see Fischer and Summers (1989) who show how better protection may end up causing more inflation.
} 
exchange rate and the correlation between expenditures and inflation are important determinants of the composition of public debt.

In order to illustrate the main government incentives in issuing different public debt securities, this paper derives a simplified model of debt indexation and denomination. It models a government that wants to minimize the fluctuation of the government budget but also wants to minimize inflation. The smoothing of the budget allows for smaller changes in the tax rate, which given convex distortion costs, imply higher utility for a representative consumer.

The main trade-off can be summarized as follows. On the one hand, by issuing indexed securities the government minimizes fluctuations of the real value of its debt from inflation variability and avoids the temptation of inflating away the debt that, in equilibrium, leads to costly higher inflation. On the other hand, if expenditure shocks are positively correlated to inflation shocks, nominal securities serve as implicit contingent debt, reducing the value of debt when it is more needed.

In addition the paper investigates when it is preferable to issue foreign denominated securities. The latter should be preferred when the real exchange rate does not fluctuate substantially and the correlation between the real exchange rate shocks and government expenditures is negative.

The paper is organized as follows. The next section summarizes Brazilian experience with indexation. Sections 3 presents the model and section 4 looks at the composition of public debt in Brazil. Finally, section 5 concludes.

\section{Indexation in Brazil}

Most of Brazilian institutionalization of indexation dates back to 1964 during the first military government of President Castelo Branco. ${ }^{2}$ Before that two laws inhibited the emergence of automatic adjustments of contacts. The first, the 1933 law passed by President Vargas simply prohibited contracts from being stipulated in currencies other than the Mil Reis, the Brazilian currency at that time. Besides being a nationalistic reaction in favour of the Brazilian sovereign monetary unit, the law attempted to curb established practice of foreign companies in Brazil to index their prices to the exchange rate in order to neutralize the effect of the devaluation of Mil Reis in their receipts

\footnotetext{
${ }^{2}$ This section draws on Simonsen (1995).
} 
measured in foreign currency. From an economic point of view, the law was based on the fact that exchange rate indexation impaired significantly the correction of balance of payment imbalances.

The second law, the "Lei da Usura" simply established a nominal interest rate celing of 12 percent. Since inflation most of the time exceeded this ceiling implying negative real rates, several mechanisms were established to bypass the law. However, long term contracts were nonexistent since they required explicit indexation mechanisms to deal with uncertainty with respect to future inflation rates.

In 1964 , the military government decided to reduce the distortions in the economy resulting from the two laws above and introduced the "correção monetária", a sophisticated indexation mechanism that adjusted taxes, tariffs and some financial contracts but not the exchange rate, wages and bank deposits. The government wanted to avoid the negative effects the absence of indexation had on public receipts and in some financial contracts. The abscence of indexation on the exchange rate and wages was justified to allow corrections of external imbalances and to avoid inflationary consequences of wage indexation.

In addition, the government issued the Obrigações Reajustáveis do tesouro Nacional (ORTN). These were public debt securities with maturities from 1 to 20 years that were adjusted automatically for past inflation plus interest rates of 6 percent per year. The objective was to avoid financing the deficit through inflationary monetary expansion. The government believed that indexing the debt would increase the demand for long term securities with fixed real rates and also allow for lower debt service since it expected inflation to decline below market expectations embedded in nominal interest rates paid on nominal securities.

The ORTN rapidly became an important reference value for other contracts. Starting in 1964, mortgage contracts were adjusted by the quarterly variation of the ORTN. This adjustment became known as the UPC (the unit of reference of capital).

Beginning in 1967, during the Costa e Silva government, indexation spread to almost all areas of the economy. Wages could no longer be denied automatic indexation. The exchange rate policy followed a Purchasing Power Parity rule and rents were adjusted every 6 months. In short, the Brazilian economy became highly indexed.

In the next two governments, from 1974 to 1985 , both indexation and in- 
flation continued to increase. The Mexican default and the consequent crisis led to higher inflation and renewed efforts to implement restrictive monetary and fiscal policies. With the economy highly indexed to past inflation, all attemps to reduce inflation through traditional policy instruments proved inappropriate.

The inflation process was thought to be inertial and its reduction to require measures that eliminate widespread indexation in the economy. In March 1986, the Cruzado plan, the first of a long series of stabilization plans was implemented. This first attempt was unsuccessful as were the following 4 plans (Bresser, Verão, Collor I and Collor II) as its evident from Figure 1. The widespread indexation of contracts persisted and the inflation continued to increase.

With high levels of uncertainty with respect to inflation nominal contracts could not survive. During the megainflation process before the Collor plan, the proportion of nominal public debt reached zero. Figure 2 shows the proportion of nominal debt in the hands of the public.

The Real plan of July 1994 succeded in reducing inflation. It was an ingenous scheme of changing numeraires. In March 1994 nominal prices, wages and other contracts were allowed to be quoted in a unified reference value (URV) that would be replaced by a new currency, the Real, on July, 1994. Since prices were already indexed to several different references, the innovation of the URV was to coordinate a unified unit of account that would substitute for all other indexation mechanism. In the interim period after the introduction of the URV and before its replacement by the real, it was expected that relative prices would converge to their equilibrium value. This was important to the second phase of the conversion, when the URV would be transformed into Real on a one-to-one basis and then pegged to the dollar. This pegging, in fact, caused inflation to plunge from 46 percent in June 1994 to 1.5 percent in September 1994.

With lower inflation and deliberate government legislation to deindex the economy, indexation of short term contracts was reduced substantially. In particular, the proportion of indexed public debt diminished substantially. Figure 4 shows the composition of public debt after the Real plan. The most striking fact is that the proportion of nominal debt debt has been increasing substantially as one should expect from the increasingly stable inflation environment. 


\section{Model}

This section focuses on the trade-off described in the introduction. The government decision to manage its public debt depends on the trade-off between time consistency problems versus tax-smoothing motives. The former generates a higher inflation than optimal which requires, in order to credibly commit to low inflation, a structure based on indexed securities (to either foreign or domestic inflation). Tax smoothing calls for issuing any security whose returns are negatively correlated with the tax needs of the government. This may be the case of both nominal and foreign currency linked debt.

An optimal composition of debt between nominal, indexed and foreign denominated liabilities is derived in a two period example. The objective is to highlight the effects of both tax smoothing and time consistency considerations on the optimal composition in the simplest possible framework. ${ }^{3}$

The objective of the government is to minimize distortions from taxes $(\tau)$ and inflation $(\pi)$, both assumed to be quadratic. There are three sources of uncertainty: government spending, real exchange rate and money demand are assumed to be stochastic. The latter introduces uncertainty with respect to the rate of inflation,

$$
\operatorname{Min} E\left[A \frac{\tau^{2}}{2}+\frac{\pi^{2}}{2}\right]
$$

In the first period, the government will choose the composition of the debt that it sells to the public and that will mature at the end of period two. There are three financial instruments available: (i) nominal bonds that are sold at a nominal interest rate $i$ and have a realized rate of return of $\frac{(1+i)}{(1+\pi)}$ (ii) indexed bonds that pay a real rate of $r$ plus the realized rate of inflation $\pi$ and (iii) foreign denominated bond that pay the foreign interest rate $i^{*}$ plus the rate of depreciation $e$ and have a realized real rate of return in domestic currency equal to $\frac{\left(1+i^{*}\right)(1+e)}{(1+\pi)}$.

There are no shocks or other financing decisions in the first period. In the second period, given the level of debt and its composition, the government decides about the optimal money growth. After that, the shocks are realized and taxes are levied to balance the budget. ${ }^{4}$

\footnotetext{
${ }^{3} \mathrm{~A}$ multiperiod model is developed in Goldfajn (1996). For a related model of public debt indexation see Calvo and Guidotti (1990).

${ }^{4}$ The budget has to balance since $i t$, is the last period. In the multiperiod model, taxes
} 
Consumers are in the background, they enter the model as risk neutral debt holders and will demand a nominal interest rate which includes a fixed real interest rate $(\mathrm{r})$ plus the expected rate of inflation $\left(\pi^{e}\right):{ }^{5}$

$$
1+i=\left(1+\pi^{e}\right)(1+r) .
$$

The assumption of risk neutrality of the investors is not restrictive and is done for simplicity. If I had assumed risk averse investors, they would have demanded an extra premium to hold nominal debt but the main results would still hold. ${ }^{6}$

The paper assumes uncovered interest rate parity:

$$
1+i=\left(1+e^{e}\right)\left(1+i^{*}\right)
$$

The money market equation determines the equilibrium inflation rate:

$$
\pi=\hat{m}+\tilde{v},
$$

where, $\hat{m}$ is money supply growth created by the government and $\tilde{v}$ are velocity shocks that are assumed to be white noise. Here the paper assumes that the government sets the money supply and lets the nominal exchange rate be determined endogenously. ${ }^{7}$

In equilibrium, rational investors will anticipate the money supply growth decision of the government. In the model, this implies that investors anticipate the average inflation generated by the government:

$$
\pi^{e}=E[\pi]=\hat{m}
$$

The budget constraint of the government in period 2 is that taxes have to be equal to spending plus the real value of debt. ${ }^{8}$ Using equations 2 and 3 and linearizing the budget constraint I obtain:

and money growth are decided simultaneously and the amount of debt financing adjusts for the shocks.

${ }^{5}$ It is assumed that the real interest rate $r$ is equivalent to the one demanded on indexed bonds. Even with risk neutrality, equation 2 is an approximation.

${ }^{6}$ The results depend on the fact that the government wants to minimize the fluctuations on the real value of its debt since they generate costly changes in the tax rates. The degree of risk aversion of the investors does not change this fact.

${ }^{7} \mathrm{An}$ alternative and equivalent assumption will be to allow the government to set the rate of depreciation and let money be determined endogenously.

${ }^{8}$ For simplicity revenues from cash balance holdings are ignored. 


$$
\tilde{\tau}=\tilde{G}+(1+r) B\left[1-\theta\left(\tilde{\pi}-\pi^{e}\right)-\theta^{*}\left(\tilde{q}-q^{e}\right)\right],
$$

where $\theta$ and $\theta^{*}$ are the proportions of nominal and foreign denominated debt, respectively, $B$ the level of total debt, and

$$
\tilde{q}=\tilde{\pi}-\tilde{e} .
$$

Unexpected increases in inflation reduce nominal debt and unexpected real appreciations reduce foreign denominated debt (assume for simplicity that foreign inflation is zero).

\section{Commitment Solution}

First the commitment solution will be derived. It is assumed that government at 1 can credibly commit the decisions taken by government at 2 . Therefore, in period 1 the government will choose both the composition, $\theta$ and $\theta^{*}$, and the way government 2 will finance itself between taxes and money growth. Minimizing 1 subject to 5 and 6 , I obtain the following solution:

$$
\hat{m^{*}}=0
$$

and the optimal proportions are:

$$
\begin{aligned}
\theta & =\frac{\sigma_{g \pi} \sigma_{q}^{2}-\sigma_{g q} \sigma_{\pi q}}{B\left[\sigma_{\pi}^{2} \sigma_{q}^{2}+\left(\sigma_{\pi q}\right)^{2}\right]} \\
\theta^{*} & =\frac{\sigma_{g q}}{B \sigma_{q}^{2}}-\frac{\sigma_{\pi q} \theta}{\sigma_{q}^{2}}
\end{aligned}
$$

where $\sigma$ denotes variance or covariance of the subscripts. It is assumed, for simplicity, that $r=0$.

The optimal money supply growth is zero because there are no benefits from announcing a higher money path since nominal interest rates will increase proportionally to higher inflation rates. Moreover, higher inflation rates imply higher distortion costs, so that governments will optimally commit to a zero inflation path.

The optimal proportion of the debt in nominal terms increases with the covariance of inflation with spending but diminishes with the variance of inflation. The intuition is that shocks to the other components of the budget 
should be optimally hedged. On one hand, nominal debt is a good hedging device for the government whenever shocks to spending (or any other component of the primary deficit) are positively correlated to inflation shocks and, therefore, negatively correlated to the debt value. This avoids having to raise taxes in bad states of the world.

On the other hand, pure inflation variance only introduces noise to the budget and induces the use of more indexed debt. This will be the case in countries that face large nominal shocks relative to real movements. The real value of the their debt would fluctuate without a corresponding change in other budgetary components. This induces the use of a high proportion of indexed debt. In the empirical section of the paper, we will see that this is precisely the case of Brazil.

It is interesting to note the effect of having liabilities in foreign currency. They introduce another instrument for hedging, provided the correlation between the real exchange rate and other domestic budget components (in this case spending) are not zero.

The trade-off with foreign denominated liabilities is that they may introduce more noise to the budget. If the value of foreign currency used to peg part of the debt is not very stable, i.e. , with a high variance of the real exchange rate, taxes will fluctuate more to compensate the movements in the real value of foreign denominated debt.

It is interesting to note that the optimal proportions of nominal and foreign denominated debt derived above imply a specific relationship between them. A larger share of nominal debt is associated with a larger share of foreign denominated debt depending on whether the covariance between inflation and the real exchange rate is positive or negative. If the returns covary negatively, both bonds are complements in the governments portfolio and they should increase proportionaly.

\section{Absence of Commitment}

The assumption of commitment is relaxed.

If the government cannot commit its future behavior, it will face time consistency problems, arising from the fact that it controls the average inflation rate. In period 2 , it will be optimal to inflate some of the existing nominal debt. Ex-ante, rational investors will anticipate the future temptation to inflate, adjust expected inflation and demand a higher nominal interest 